\title{
THE INFLUENCE OF FAMILY RELATIONSHIPS ON PARENTING IN THE HERITAGE OF EASTERN THINKERS
}

\author{
Nizami Rasulova Iroda \\ Lecturer of the Shakhrisabz branch of TSPU im. \\ Nizami Ergasheva Maftuna \\ Student of the Shakhrisabz branch of TSPU im.
}

Article DOI: https://doi.org/10.36713/epra2114

\begin{abstract}
ANNOTATION
This article discusses the role of Eastern thinkers in the family, interpersonal relationships in the family, as well as the role of parental responsibilities and their role in the present.
\end{abstract}

KEY WORDS: Education, philosophical, moral-psychological, ideological, Avesto, upbringing, knowledge.

\section{DISCUSSION}

Our outstanding scientists, who lived and worked in the ancient East, focused on the family, parenting and healthy parenting, regardless of what areas of research they are looking for. We see that family relationships are reflected in our national values and in the historical and spiritual heritage of our great thinkers.

These include the books of Avesta Eros Enasoy, "Wise People" by Yusuf Khos Hajib, "City of Good People" by Abu Nasra Farabi, "Ancient Monuments of Abu Raikhan Beruni", "The Law of Medicine" by Abu Ali Ibn Sina, Noble ideas of family education, as is known from stories are passed down from generation to generation with their philosophical socio-psychological views.

The idea that unites all Eastern thinkers is that they put the role of family and family upbringing in the development and upbringing of the person, paying special attention to the leadership and educational responsibilities of parents and close people in the intellectual and moral development of the person.

In their works we see a number of positive qualities that can be found in the family, such as honesty, honesty, hard work, honesty, courage and kindness, which are reflected in their philosophical and moral-psychological views.

In particular, Avesto, the main book of Zoroastrianism in Central Asia, pays particular attention to family relations. Avesto says that the father is the main leader in raising a child based on the following motives for marriage:

- love because of love;

- Will of parent or guardian due

- a desire to have children;

- It is also said that in Avesto it is strictly forbidden to marry offspring.

In general, the emphasis of Zoroastrianism on family problems can also be seen in well-known words about the social importance of parenting.

The contribution of our great-grandfather

Mir Alisher Navoi to the spiritual and ideological views of man is invaluable.

In each of the works of Navoi, special attention is paid to the education of perfect people. Navoi's book Mahbub-ul-Kulub (Love of Hearts) describes the observations that he studied throughout his life about the good and bad qualities of family traditions of the way of life of ordinary people. 
Navoi's views on the family values of the couple's happiness and qualities are of great psychological importance and are necessary for young people to be ready for family life, as they form a positive image of their national values and, thus, form a positive outlook on their family. In each of his works, Navoi considers perfectionism and its positive qualities as the fruit of parenting and upbringing in the family. Alisher Navoi glorifies the good qualities of parents in his works. It is said that such qualities as well-being in them, that is, an integrated family, play an important role in the influence of older people on the upbringing of children. She believes that paternity is the main driving force behind her vision. "The condition and happiness of a good wife. The peace and tranquility of the landowner is here. If it's good, it's satisfying and good-natured. Discipline is discipline in the household. If he does not know, his heart will suffer. If you are a drunkard, you will lose your manners and your family will be disgraced if you are unreasonable" 1 . Alisher Navoi argues that an example of a mother in a family is that her behavior is largely in the public domain and that a role model for her child can be turned negative. $\mathrm{He}$ is particularly concerned about the imperfection of the parent's spirituality, which can lead to irreversible defects in the development of the child. This is reflected in the following byte:

Who says: "If a dog with a puppy is a thousand A dog is a man without a donkey.

These verses say that Navoi is primarily a family environment, that is, a child grows and imitates in the same way as a parent brings up a family.

Navoi's views on the family values of the couple's happiness and qualities are of great psychological importance and are necessary for young people to be ready for family life, as they form a positive image of their national values and, thus, form a positive outlook on their family. In conclusion, it is important to note that each of the works of a great thinker is an important source of education for our youth based on our national values.

According to Abu Nasr Farabi, one of the great scientists of the East, the influence of the environment and upbringing can shape the moral character of the family. Farabi believes that the concept of morality is inextricably linked with the nature of man. According to him, there are 4 obstacles to the full development of the human personality. These are:

- Disrespect

- Moral

- Variability

- Doubt

\footnotetext{
${ }^{1}$ Alisher Navai Mahbub-ul-Kulub (Love of Hearts) 1.11. T.
}

In addition, Farabi expresses his opinion about the rigidity and softness of education. This, in turn, is one of the main ideas and methods of educational psychology. In Farabi's poems, "The City of Good People" and "The Way to Happiness," eastern delicacy between parents and children is a matter of love and respect. Therefore, he points out that the values left by his ancestors should be respected by tradition and tradition. To do this, she offers parents to raise their children in the family based on traditions and customs. ${ }^{2}$

Describing the image of a well-educated person, Farabi says: "If someone says that he has not learned wisdom, let him start at an early age and know his health.

All people love when their behavior is beautiful. A person whose behavior is correct will go online.

When a broken father is in the family, the child's behavior as a child grows. When the father controls the child, he is conscientiously brought up and brought up. When a good action comes with white milk, it does not change until death. What does the boy know when he or she grows up and dies until she dies.

It is noteworthy that Abu Rayhan Beruni and Abu Ali Ibn Sina, known as the great thinkers and geniuses of that time, are known for their wise thoughts and ideas. They believe that in good deeds, special attention will be paid to the role of work experience and observation in raising a child and only in a fair and healthy family environment.

Of particular note are the views of orientalist Abu Raikhan Beruni on family relationships. In his works, Biruni pays particular attention to the education of women. In her book Mineralology, she gives advice on raising married girls, arguing that the family world is the responsibility of most women in raising children. Good deeds emphasize the importance of work experience and observation in personal education and firmly believe that a child will exist only in a fair and healthy family environment. ${ }^{3}$

Ibn Sina's views on moral and ethical factors in personal education are included in his "Treatise on Ethics", namely: "Brochure on the Family", "Book of Justice", "Brochure", "Book of Justice". events ". The pedagogical and psychological views of Ibn Sina are built on a social basis, which emphasizes that the use of universal values in parenting also plays an important role in parenting in the future. Ibn Sina talks about the way of life in his thoughts about the moral education of the child. Raising a child is the main goal of a family

\footnotetext{
${ }^{2}$ Farabi "The City of Good People" chapter 3.305 . T.

${ }^{3}$ School against. Scientific and methodological journal 2014
} 
parent. A parent teacher who is able to correct his or her deficiencies is the most important tool. In a moral context, the scientist's emphasis on the role of the family can be seen in the fact that he addressed the issue of family and family relations in his book "The Conversion of the Lord". In the section "Avsofi behtarini zanho" ("Best Women") of the book "Turn to Business" her ideas about the family, especially in raising children, are exemplary.

Yusuf Khos Hajib, a great thinker and poet of the eleventh century, in his book "Knowledge Leading to Happiness" explains his views on the culture of communication in the family and the public, commenting on the concepts of good and evil, nobility and decency ${ }^{4}$. He believes that communication and socially useful work is the main criterion for the development and survival of a person only in society.

It is well known that the family is the foundation of society. He writes about adjectives based on family values. That is why Yusuf Khos Hajib was considered the cornerstone of the moral development of the child. Thus, we see that the family environment, upbringing and high responsibility of parents in relation to their child and his achievement are also mandatory. Yusuf Khos Hajib "If the boy's behavior is bad, the child is innocent. All the fault lies with his father." That is why parents, especially the father, should pay great attention to this.

One of the most famous teachers of the East According to Avloni, the social environment and family circumstances play an important role in the formation of moral values in children. Avloni emphasizes the role of the family in the development of the child as an individual and says: "This is what you do in a double room" "When asked about the rule of thumb, she says that this is the first home education, when the mother's work is the second and the madrassa teacher's. ${ }^{5}$

This father is a teacher and government official. "In conclusion, parenting begins with the family and emphasizes the role that the mother plays in this. In general, the masterpieces show that the peoples of the East pay great attention to the spiritual education of the child through family rites.

It is well known that family life is closely connected with the life of society and never loses its relevance. The fact that family and family relations have a long history can be seen in the folklore of our people, which is passed down from generation to generation. Also in the hadiths of the Holy Quran, we can see in the works of oriental scholars that the

\footnotetext{
${ }^{4}$ I.A.Karimov "Yuksak ma'naviyat yengilmas kuch" 5. 2008. Toshkent "Manaviyat"

5 “Ma'naviyat yulduzlari” A.A.nashriyoti. Toshkent 1999
}

interpersonal relationships of the family in parenthood and the obligation of children to educate the bride about the couple's responsibility for choosing the bride's marriage. In general, the inhabitants of the East attach great importance to the spirituality of the child and his willingness to live independently. He says that all the good qualities of a parent in a family are enriched by an example of good parenting, that is, children should be guided not just by good advice, but by the conviction of their children to do good. In addition: "Those who say that this is evil do not work, and that if they do this evil, they will sow oats on the earth that will not do them any good. When this happens, children should learn to bring up a good upbringing, and not just hear the dignity of humanity from only one language". These ideas can be a guide to proper parenting. It is from the ideas of Eastern thinkers that a personality is formed in the family and on the basis of family values. We can see that the views of the family as the primary social environment in the minds of our thinkers and the healthy views of the person's personality have not lost their father's particular relevance in raising faith-related issues of faith. The human qualities they have formed are an important factor in expressing human excellence.

In conclusion, many aspects of education are directly related to the moral maturity of the parents and the warmth of the warm relationship between them and the psychological climate in the family. Because the moral image of parents in the family plays an important role in raising children.

\section{BIBLIOGRAPHY}

1. Alisher Navoi. Mahbub-ul-kulub-T Fan 1983

2. Farabi "The City of Good People" chapter 3. 305. $T$.

3. School against. Scientific and methodological journal 2014

4. I.A.Karimov "Yuksak ma'naviyat yengilmas kuch" 5. 2008. Toshkent "Manaviyat"

5. Ma'naviyat yulduzlari" A.A.nashriyoti. Toshkent 1999 